\title{
Mendongkrak Imunitas dari Pekarangan Rumah
}

Kurniatul Hasanah ${ }^{1}$

${ }^{1}$ Politeknik Kesehatan Hermina

E-mail: niasai25@gmail.com

Dia Septiani ${ }^{2}$

${ }^{2}$ Politeknik Kesehatan Hermina

E-mail: dia.septiani@gmail.com

\section{Devi Maulina ${ }^{3}$}

${ }^{3}$ Politeknik Kesehatan Hermina

E-mail: maulinadevi2011@gmail.com

\section{Dwi Kurnia Putri ${ }^{4}$}

${ }^{4}$ Politeknik Kesehatan Hermina

E-mail: dkurniaputri15@gmail.com

Milda Rianty Lakoan ${ }^{5}$

${ }^{5}$ Politeknik Kesehatan Hermina

E-mail: mildariantylakoan@gmail.com
Article History:

Received: 2021-12-03

Revised: 2022-01-10

Accepted: 2022-01-25
Abstract: Efforts to maintain the body's immunity to avoid exposure to Corona virus infection can be done by consuming natural ingredients native to Indonesia from the surrounding environment. The public is expected to know the mechanism of infection and its relation to human immunity. The method used is the presentation of material about the mechanism of infection and its relation to the human body's immunity, getting to know native Indonesian herbs and how to grow herbs in a simple way in the yard, demonstrations of herbal processing and making fertilizer with the takakura method. The target and outcome of this activity is to increase community knowledge and skills regarding the mechanism of infection and its relation to human immunity, knowing native Indonesian herbs and how to process them at home, and making organic fertilizers. The result of this activity was an increase in public knowledge, namely an increase in the 
achievement of the knowledge score of 100 participants in the pretest and posttest from 119 participants (21.25\%) to 297 participants (49.42\%), or an increase of

Keywords: Covid-19 pandemic, immunity, $28.17 \%$.

herbs

Riwayat Artikel :

Diajukan: 03-12-2021

Diperbaiki: 10-01-2022

Diterima: 25-01-2022
Kata kunci: Pandemi Covid-19, herbal, metode takakura, PkM, prodi D-III Farmasi, Poltekkes Hermina
Abstrak: Upaya menjaga imun tubuh untuk menghindari paparan infeksi virus Covid-19 dapat dilakukan dengan mengonsumsi bahan-bahan alami asli Indonesia dari lingkungan sekitar. Masyarakat diharapkan mengetahui mekanisme infeksi dan kaitannya dengan imunitas tubuh manusia. Metode yang digunakan adalah pemaparan materi tentang mekanisme infeksi dan kaitannya dengan imunitas tubuh manusia, mengenal herbal asli Indonesia dan cara menanam herbal secara sederhana di pekarangan rumah, demonstrasi pengolahan herbal dan pembuatan pupuk dengan metode Takakura. Target dan luaran dari akhir kegiatan Pengabdian kepada Masyarakat (PkM) ini adalah meningkatkan pengetahuan dan keterampilan masyarakat mengenai mekanisme infeksi dan kaitannya dengan imunitas tubuh manusia, mengetahui herbal asli Indonesia dan cara mengolahnya di rumah, serta pembuatan pupuk organik. Hasil kegiatan ini adalah terjadi peningkatan pengetahuan masyarakat, yaitu peningkatan pencapaian nilai pengetahuan 100 poin peserta pada pretest dan posttest dari 119 peserta (21,25\%) menjadi 297 peserta (49,42\%), atau meningkat sebanyak $28,17 \%$. 


\section{Pendahuluan}

Pandemi virus Covid-19 menyebabkan banyak perubahan dalam kehidupan sehari-hari. Gizi yang baik juga sangat penting sebelum, selama dan setelah infeksi. Infeksi menyebabkan tubuh korban menjadi demam, sehingga membutuhkan tambahan energi dan zat gizi. Oleh karena itu, menjaga pola makan yang sehat sangat penting selama pandemi ini. Sampai saat ini belum terbukti ada makanan atau suplemen makanan yang dapat mencegah infeksi Covid-19, akan tetapi mempertahankan pola makan gizi seimbang yang sehat sangat penting dalam meningkatkan sistem kekebalan tubuh yang baik. Meskipun vaksin untuk mencegah virus Covid-19 sudah didistribusikan, upaya menjaga kesehatan supaya tidak terinfeksi virus Covid-19 tetap perlu dilakukan. Upaya yang bisa dilakukan untuk menghindari paparan dari infeksi virus Covid-19 adalah dengan meningkatkan sistem imun dan daya tahan tubuh (Amalia et al., 2020). Upaya tersebut diantaranya adalah dengan mengonsumsi bahan-bahan alami yang berasal dari Indonesia yang bisa diperoleh dari sekitar rumah. Berdasarkan hal tersebut pada kegiatan PkM kali ini kami memilih melaksanakan kegiatan edukasi yang bersifat tindakan promotif dan kuratif kepada masyarakat melalui webinar PkM Prodi D-III Farmasi dengan judul "Mendongkrak Imunitas dari Pekarangan Rumah".

\section{Metode}

Di saat pandemi covid-19 pemberlakuan Pembatasan Sosial Berskala Besar (PSBB) untuk menekan penyebaran COVID-19 semakin meluas, didasarkan pada pertimbangan epidemiologi, besarnya ancaman, efektivitas, dukungan sumber daya, teknis operasional, pertimbangan politik, ekonomi, sosial, budaya, pertahanan dan keamanan (Kemenkes RI, 2020). Keadaan tersebut dilanjutkan dengan Pemberlakuan Pembatasan Kegiatan Masyarakat (PPKM) serta Pemberlakuan Pengetatan Kegiatan Masyarakat (PPKM) Level 4, 3, dan 2 (Mendagri, 2021). Ada beberapa hal yang dialami masyarakat secara umum pada saat ini, yaitu:

a. Kekhawatiran yang cukup besar dirasakan oleh masyarakat terhadap penularan virus Covid-19.

b. Perlunya upaya masyarakat untuk meningkatkan imunitas tubuh. 
c. Meningkatnya derajat kejenuhan masyarakat karena harus melaksanakan kegiatan sehari-hari seperti beribadah, berolahraga, bekerja, sekolah dan lain-lain di dalam rumah.

Berdasarkan analisis situasi dan permasalahan di atas tim pengusul kegiatan pengabdian kepada masyarakat berkeinginan membantu masyarakat meningkatkan pengetahuan mengenai mekanisme infeksi dan kaitannya dengan imunitas tubuh manusia, mengetahui herbal asli Indonesia yang bisa digunakan untuk menjaga imunitas tubuh serta cara mengolahnya sehingga bisa dibuat sendiri di rumah, dan pembuatan pupuk dari sampah organik yang berasal dari sampah rumah tangga menggunakan metode Takakura.

Metode yang digunakan dalam kegiatan PkM ini adalah partisipasi aktif dari kelompok masyarakat dengan pelatihan antara lain:

a. Melakukan pretest dengan mengisi beberapa soal terkait materi yang akan disampaikan.

b. Sosialisasi tentang mekanisme infeksi dan kaitannya dengan imunitas tubuh manusia serta mengenai herbal asli Indonesia yang bisa digunakan untuk menjaga imunitas tubuh.

c. Mendemonstrasikan cara pembuatan beberapa jenis jamu.

d. Mendemonstrasikan cara pembuatan pupuk dari sampah organik yang berasal dari sampah rumah tangga menggunakan Metode Takakura.

e. Memberi penugasan kepada peserta untuk membuat video pembuatan jamu.

f. Diskusi dan tanya jawab materi yang sudah diberikan.

g. Melakukan evaluasi dengan posttest dan kuesioner.

Pemecahan masalah pertama terkait kekhawatiran yang cukup besar dirasakan oleh masyarakat terhadap penularan virus Covid-19 adalah dengan pemaparan materi mengenai Infeksi dan Imunitas Tubuh Manusia. Materi yang disampaikan terdiri dari:

1. Respon imun terhadap infeksi virus yang tergantung dari jenis virus, jalur transmisi, dan kemampuan replikasi di dalam sel host (Nicholson, 2016). 
2. Tiga mekanisme virus dalam menginisiasi respon imun, yaitu melalui interferon, antibodi dan mekanisme sitotoksik (Levy et al., 2000).

3. Meningkatkan sistem imun dengan memperhatikan pola makan, aktivitas fisik dan istirahat yang cukup serta meminimalkan stress.

Pemecahan masalah kedua mengenai perlunya upaya masyarakat untuk meningkatkan imunitas tubuh adalah dengan pemaparan materi mengenai herbal asli Indonesia. Materi yang disampaikan terdiri dari:

1. Herbal asli Indonesia yang dapat dikonsumsi untuk meningkatkan imunitas tubuh. Beberapa tanaman yang sudah mempunyai bukti secara ilmiah dapat dikonsumsi untuk meningkatkan daya tahan tubuh yang bisa ditemui dengan mudah di lingkungan rumah antara lain jahe, temulawak, jambu biji, sambiloto dan kunyit (Suhendra et al., 2020).

2. Cara menanam herbal secara sederhana di pekarangan rumah. Tanaman obat keluarga (TOGA) menjadi salah satu pilihan untuk ditanam di lahan pekarangan karena dapat dimanfaatkan untuk kesehatan. Toga dapat berfungsi sebagai sarana untuk mendekatkan tanaman obat kepada upaya-upaya kesehatan masyarakat seperti upaya preventif (pencegahan), upaya promotif (meningkatkan/ menjaga kesehatan) dan upaya kuratif (penyembuhan penyakit) (Bebet \& Mindarti, 2015).

3. Demonstrasi Cara Mengolah Herbal, yaitu melakukan pemutaran dan penjelasan video mengenai pembuatan tiga jenis jamu yang paling populer di masyarakat terutama di masa pandemi seperti sekarang ini.

Pemecahan masalah ketiga terkait meningkatnya derajat kejenuhan masyarakat karena harus tetap berada di dalam rumah dalam melaksanakan kegiatan sehari-hari termasuk beribadah, berolah raga, bekerja atau sekolah dari rumah dan lain-lain ditindaklanjuti dengan demonstrasi pembuatan pupuk dari sampah organik (Metode Takakura). Takakura adalah salah satu cara pembuatan pupuk kompos yang bisa dilaksanakan oleh masyarakat umum karena metodenya sederhana dan mudah diaplikasikan (Rosmala et al., 2020). Cara ini dapat mengurangi pembuangan sampah di Jakarta yang menurut Dinas Lingkungan Hidup DKI 
Jakarta produksinya mencapai 7.000 ton setiap hari (Wisman et al., 2013). Selain itu cara ini juga bisa menghasilkan pupuk organik untuk digunakan sebagai penyubur TOGA. Kegiatan pembuatan pupuk juga diharapkan sebagai salah satu kegiatan yang dapat dilakukan dalam mengisi waktu luang di rumah khususnya pada saat Pemberlakuan Pembatasan Kegiatan Masyarakat (PPKM) sehingga dapat mengurangi tingkat kejenuhan.

\section{Hasil dan Diskusi}

Peningkatan pengetahuan peserta webinar dilihat berdasarkan perolehan nilai pretest dan posttest. Pretest diadakan pada pukul 08.30 - 10.00 WIB dengan jumlah peserta yang mengerjakan sebanyak 560 orang. Hasil dari pretest adalah sebanyak 119 peserta mendapatkan nilai pengetahuan 100 poin, 29 peserta mendapatkan nilai 96 poin, 45 peserta mendapatkan nilai 92 poin, 60 peserta mendapatkan nilai 88 poin, 72 peserta mendapatkan nilai 84 poin, 83 peserta mendapatkan nilai 80 poin, 68 peserta mendapatkan nilai 76 poin, 60 peserta mendapatkan nilai 72 poin, 17 peserta mendapatkan nilai 68 poin, 4 peserta mendapatkan nilai 64 poin, 2 peserta mendapatkan nilai 60 poin, 1 peserta mendapatkan nilai 56 poin. Hal tersebut menunjukkan pemahaman para peserta sudah cukup baik terhadap materi yang akan disampaikan oleh pembicara. Secara grafik perolehan nilai pretest peserta webinar PkM dapat dilihat pada Gambar 1.

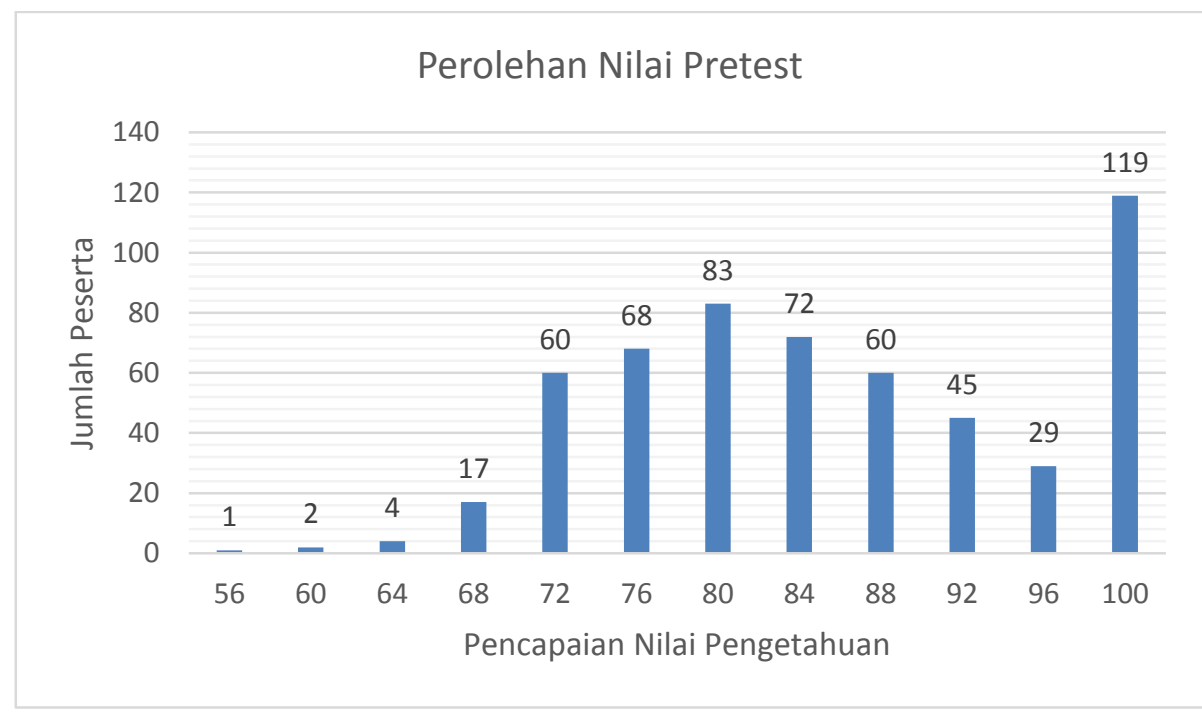

Gambar 1. Distribusi Perolehan Nilai Peserta pada Pretest Webinar PkM 
Posttest dilakukan mulai pukul 12.00 - 18.00 WIB dengan jumlah peserta yang mengerjakan sebanyak 601 orang. Hasil dari posttest adalah sebanyak 297 peserta mendapatkan nilai pemahaman 100 poin, 75 peserta mendapatkan nilai 96 poin, 44 peserta mendapatkan nilai 92 poin, 33 peserta mendapatkan nilai 88 poin, 43 peserta mendapatkan nilai 84 poin, 50 peserta mendapatkan nilai 80 poin, 26 peserta mendapatkan nilai 76 poin, 18 peserta mendapatkan nilai 72 poin, 9 peserta mendapatkan nilai 68 poin, 4 peserta mendapatkan nilai 64 poin, 1 peserta mendapatkan nilai 56 poin dan 1 peserta mendapatkan nilai 52 poin. Secara grafik perolehan nilai posttest peserta webinar PkM dapat dilihat pada Gambar 2.

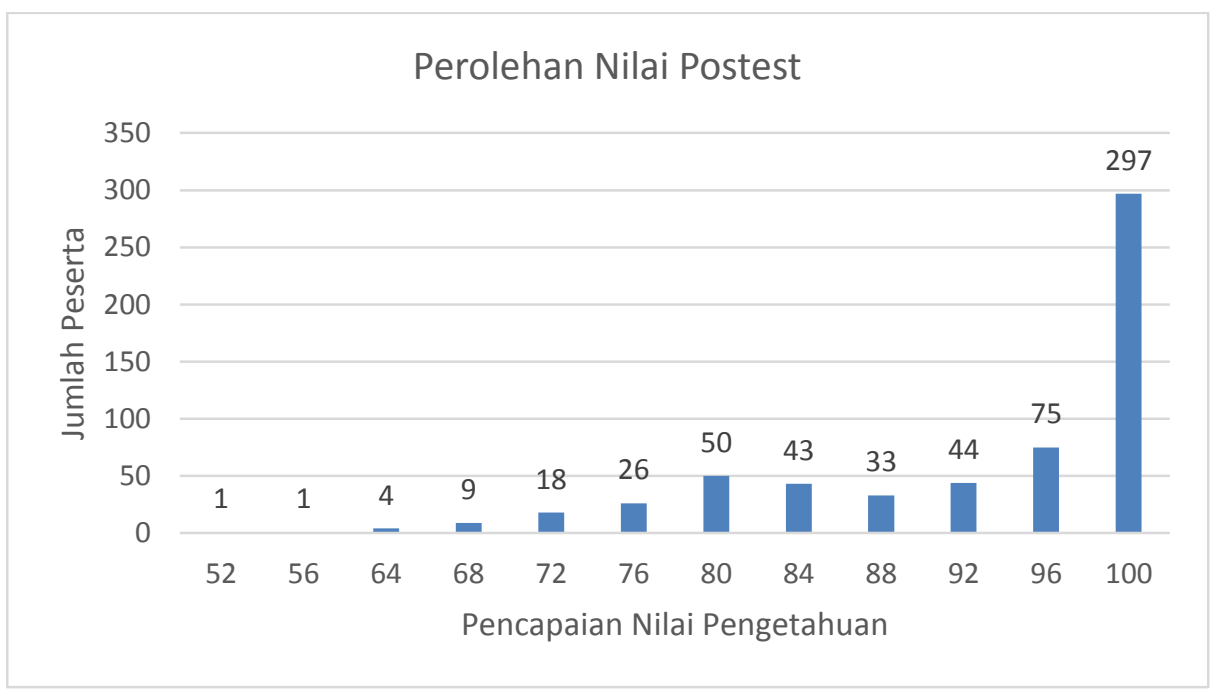

Gambar 2. Distribusi Perolehan Nilai Peserta pada Posttest Webinar PkM

Hasil nilai rata-rata posttest dibandingkan nilai pretest menunjukkan peningkatan pemahaman peserta terhadap materi yang sudah disampaikan dengan nilai 88,22 . Pencapaian nilai pengetahuan 100 poin pada posttest dibandingkan pretest meningkat sebanyak 28,17\%, yaitu dari 119 peserta (21,25\%) menjadi 297 peserta (49,42\%). Peningkatan tersebut dapat dilihat dalam grafik di bawah ini. 


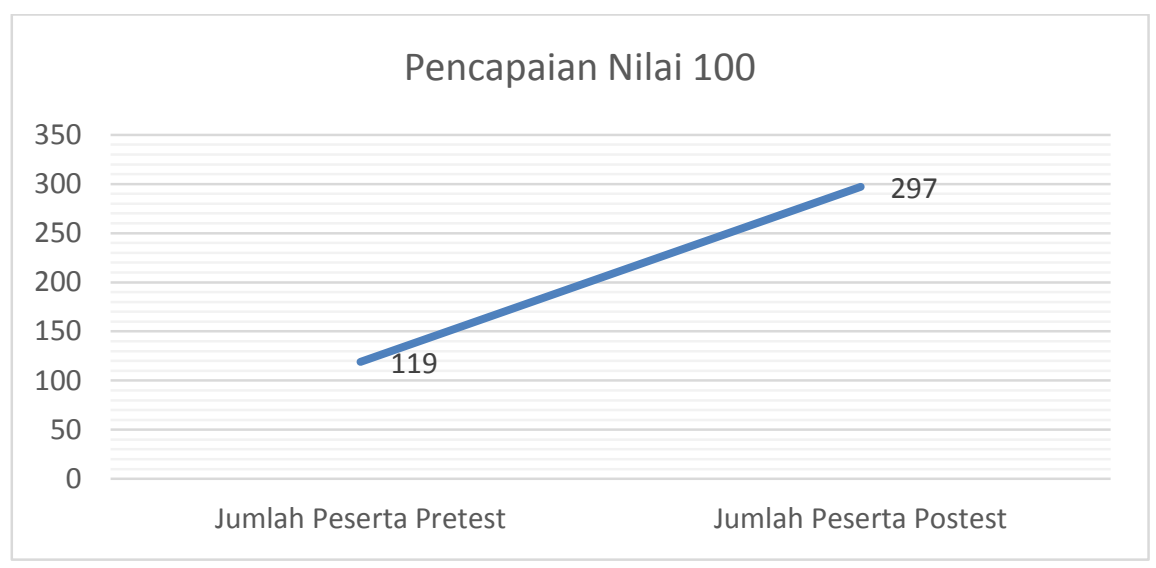

Gambar 3. Perbandingan Pencapaian Nilai Pengetahuan 100 poin Peserta pada Pretest dan Posttest

Program pengabdian kepada masyarakat ini merupakan merupakan perwujudan dari salah satu tri dharma perguruan tinggi yang telah dilaksanakan oleh Program Studi D-III Farmasi Politeknik Kesehatan Hermina dengan harapan dapat:

1. Mengurangi kekhawatiran masyarakat terhadap penularan virus Covid-19 dengan memberikan informasi dan pengetahuan kepada masyarakat mengenai infeksi dan imunitas tubuh manusia.

2. Membantu masyarakat dalam upaya meningkatkan imunitas tubuh dengan cara memberikan materi mengenai herbal asli Indonesia yang meliputi beberapa jenis tanaman yang sudah mempunyai bukti secara ilmiah dapat dikonsumsi untuk meningkatkan daya tahan tubuh yang bisa ditemui dengan mudah di lingkungan sekitar, cara menanam herbal secara sederhana di pekarangan rumah dan cara mengolah herbal untuk dikonsumsi sehari-hari.

3. Memberikan inspirasi kepada masyarakat dalam menurunkan derajat kejenuhan karena harus tetap berada di rumah dalam melaksanakan rutinitas sehari-hari dengan menyampaikan materi mengenai pembuatan pupuk dari sampah organik (Metode Takakura) yang dapat dilakukan secara sederhana dengan bahan dan alat yang mudah didapat di rumah.

Kegiatan pengabdian kepada masyarakat ini dilaksanakan pada hari Sabtu, tanggal 17 Juli 2021 melalui zoom meeting dan live streaming Youtube Poltekkes Hermina dengan jumlah peserta 822 orang yang terdiri dari 522 Apoteker, 24 orang Tenaga Teknis Kefarmasian (TTK), 266 
orang mahasiswa dan 10 orang masyarakat umum.

Sebelum pelaksanaan kegiatan dilakukan pengisian pretest pengetahuan tentang materi yang akan disampaikan dengan hasil nilai rata-rata adalah 84,68 dengan pencapaian nilai pengetahuan 100 poin sebanyak 119 peserta.

Kegiatan ini dikemas secara interaktif dengan melibatkan peserta yang mau bertanya secara langsung kepada narasumber serta memberikan kesempatan kepada peserta untuk mengimplementasikan materi webinar yang didapatkan dengan memberikan penugasan kepada peserta untuk membuat video mengenai pembuatan jamu baik salah satu jamu yang sudah dipaparkan pada materi demonstrasi ataupun jenis jamu yang biasa dikonsumsi seharihari di rumah masing-masing. Beberapa contoh herbal yang dapat diolah secara sederhana di rumah antara lain jamu kunyit asam, beras kencur dan empon-empon. Semua jamu ini memiliki efek untuk meningkatkan imunitas. Kunyit misalnya, mengandung kurkuminoid, yaitu suatu golongan flavonoid yang mempunyai 3 jenis senyawa turunan berupa kurkumin, bisdesmetoksikurkumin dan desmetoksikurkumin. Hasil uji klinis kurkumin terbukti dapat meningkatkan sistem imunitas tubuh (immunomodulator). Hasil penelitian lain menunjukkan kurkumin bersama beberapa bahan aktif berpotensi sebagai kandidat antivirus SARS-CoV-2. Hasil studi baik in vitro maupun in vivo menunjukkan bahwa ekstrak jahe memiliki aktivitas biologis, diantaranya sebagai antiinflamasi, antioksidan, antimikroba, anti kanker, immunomodulator dan antivirus. Penggunaan kurkumin baik secara tunggal maupun gabungannya bisa membantu dalam meningkatkan daya tahan tubuh (immunomodulator). Hasil penelitian telah membuktikan bahwa ekstrak etanol temulawak dapat meningkatkan sistem imun dengan memicu proliferasi sel.(Peneliti BB Pascapanen, 2020) Dan berdasarkan hasil penelitian ekstrak daun sereh dapat digunakan sebagai anti inflamasi (BPOM RI, 2012). 
JURNAL ASTA

Abdi Masyarakat Kita

Vol. 02 No. 01, Januari 2022
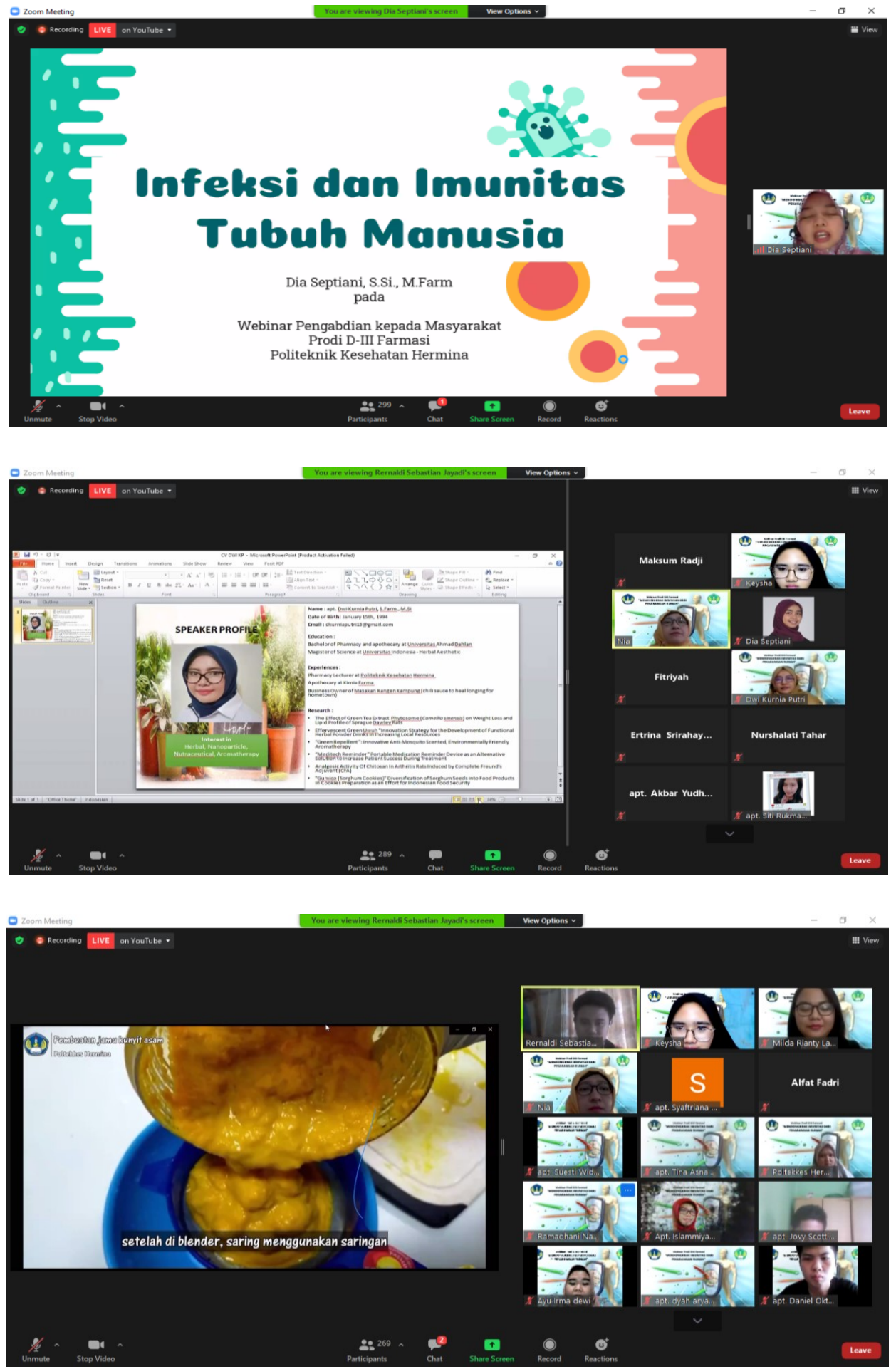
JURNAL ASTA

Abdi Masyarakat Kita

Vol. 02 No. 01, Januari 2022

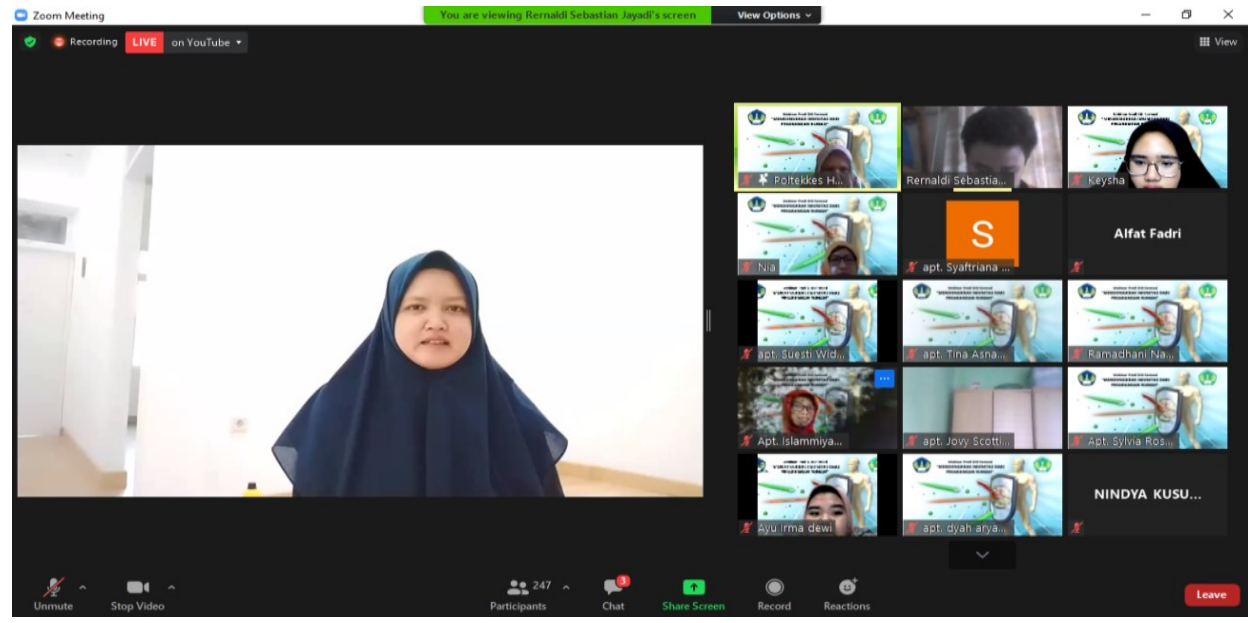

Gambar 4, 5, 6, 7. Penyampaian materi

Dari hasil diskusi banyak masyarakat yang tertarik untuk menanam tanaman herbal dan mengonsumsinya sebagai salah satu upaya untuk meningkatkan imunitas tubuh.

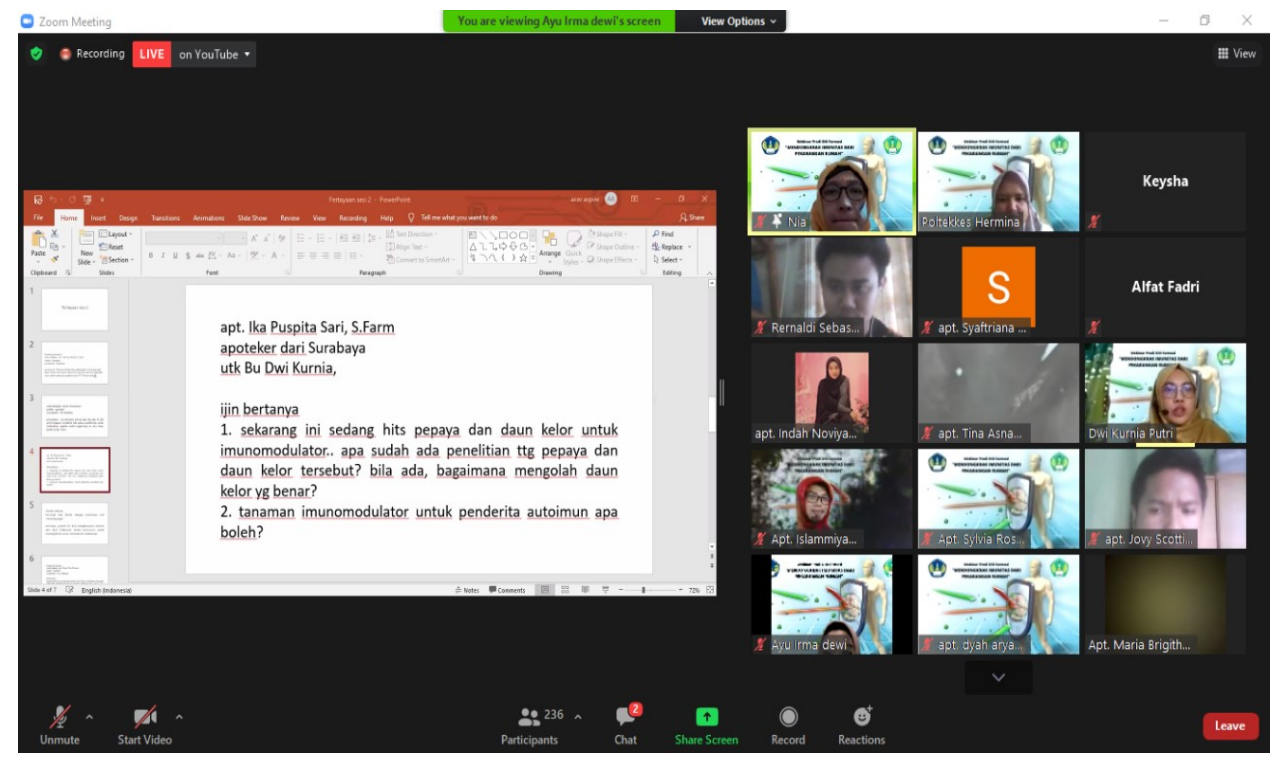

Gambar 8. Diskusi dan tanya jawab

Kegiatan selanjutnya adalah evaluasi dari penyampaian materi yang sudah diberikan. Peserta diminta melakukan pengisian posttest pengetahuan materi yang sudah diberikan.

Peserta kegiatan diminta untuk mempraktikkan pengolahan herbal yang dilakukan dengan membuat video cara membuat jamu dengan resep sederhana. 


\section{Kesimpulan}

Kegiatan pengabdian kepada masyarakat program studi D-III Farmasi Politeknik Kesehatan Hermina dengan judul Mendongkrak Imunitas dari Pekarangan Rumah memberikan manfaat sebagai berikut:

1. Meningkatnya pengetahuan dan pemahaman masyarakat tentang infeksi dan imunitas tubuh manusia.

2. Meningkatnya pengetahuan dan pemahaman masyarakat terhadap herbal asli Indonesia untuk meningkatkan imunitas tubuhdan cara menanam herbal secara sederhana di pekarangan rumah.

3. Meningkatnya pengetahuan dan pemahaman masyarakat mengenai cara mengolah herbal (jamu).

4. Memberi pengetahuan baru kepada masyarakat bahwa sampah rumah tangga dapat diolah menjadi pupuk dengan Metode Takakura.

\section{Ucapan Terimakasih}

Ucapan terima kasih disampaikan kepada Ketua beserta pengurus Yayasan Pendidikan Hermina, Direktur beserta jajaran direksi dan staf Politeknik Kesehatan Hermina, Ketua Program Studi, Tim dosen dan mahasiswa beserta civitas akademi program studi D-III Farmasi Politeknik Kesehatan Hermina, Jakarta.

\section{Daftar Pustaka}

Amalia, L., Irwan, I., \& Hiola, F. (2020). Analisis Gejala Klinis Dan Peningkatan Kekebalan Tubuh Untuk Mencegah Penyakit Covid-19. Jambura Journal of Health Sciences and Research, 2(2), 71-76. https://doi.org/10.35971/jjhsr.v2i2.6134

Badan POM RI. (2012). Acuan sediaan herbal Volume 4 Edisi Pertama. Acuan Sediaan Herbal, $1-78$.

Bebet, N., \& Mindarti, S. (2015). Buku Sakut Tanaman Obat Keluarga (TOGA). Isbn: 978-9793595-49-8, 1-24(09), 52-54.

Keputusan Menteri Kesehatan Republik Indonesia. (2020). Keputusan Menteri Kesehatan Republik Indonesia Nomor HK.01.07/MenKes/413/2020 Tentang Pedoman Pencegahan dan Pengendalian Corona Virus Disease 2019 (Covid-19). MenKes/413/2020, 2019, 207. 
Levy, A. R. R. A., Rojas-villarraga, A., \& Levy, R. A. (2000). Cancer and Autoimmunity. In Cancer and Autoimmunity. https://doi.org/10.1016/b978-0-444-50331-2.x5000-0

Menteri Dalam Negeri Republik Indonesia. (2021). Intruksi Menteri Dalam Negeri No 1 Tahun 2021 Pemberlakuan Pembatasan Kegiatan Masyarakat Untuk Pengendalian Penyebaran Covid-19. 1-4.

Nicholson, L. B. (2016). The immune system. Essays in Biochemistry, 60(3), 275-301. https://doi.org/10.1042/EBC20160017

Peneliti BB Pascapanen. (2020). Bahan Pangan Potensial untuk Anti Virus dan Imun Booster. In Bahan Pangan Potensial untuk Anti Virus dan Imun Booster.

Rosmala, A., Mirantika, D., \& Rabbani, W. (2020). Takakura Sebagai Solusi Penanganan Sampah Organik Rumah Tangga. Abdimas Galuh, 2(2), 165. https://doi.org/10.25157/ag.v2i2.4088

Suhendra, A. D., Asworowati, R. D., \& Ismawati, T. (2020). Buku Saku Obat Tradisional untuk Daya Tahan Tubuh. Akrab Juara, 5(1), 43-54. http://www.akrabjuara.com/index.php/akrabjuara/article/view/919

Wisman, J., Mengunjungi, Y., Jakarta, D. K. I., \& September, B. (2013). Bps provinsi dki jakarta (Issue 48, pp. 1-7). https://jakarta.bps.go.id/indicator/17/786/1/jumlah-kendaraanbermotor-menurut-jenis-kendaraan-unit-di-provinsi-dki-jakarta.html 